\title{
Phosphorylation of the Synaptic Protein Interaction Site on N-type Calcium Channels Inhibits Interactions with SNARE Proteins
}

\author{
Charles T. Yokoyama, ${ }^{2}$ Zu-Hang Sheng, ${ }^{1}$ and William A. Catterall ${ }^{1}$ \\ ${ }^{1}$ Department of Pharmacology and ${ }^{2}$ Graduate Program in Neurobiology and Behavior, University of Washington, Seattle, \\ Washington 98195
}

The synaptic protein interaction (synprint) site on the $\mathrm{N}$-type calcium channel $\alpha_{1 \mathrm{~B}}$ subunit binds to the soluble $N$-ethylmaleimide-sensitive attachment factor receptor (SNARE) proteins syntaxin and synaptosomal protein of $25 \mathrm{kDa}$ (SNAP-25), and this association may be required for efficient fast synaptic transmission. Protein kinase $C$ (PKC) and calcium and calmodulin-dependent protein kinase type II (CaM KII) phosphorylated a recombinant his-tagged synprint site polypeptide rapidly to a stoichiometry of 3-4 mol of phosphate/ mol, whereas cAMP-dependent protein kinase (PKA) and cGMP-dependent protein kinase (PKG) phosphorylated the synprint peptide more slowly to a stoichiometry of $<1 \mathrm{~mol} / \mathrm{mol}$. Two-dimensional phosphopeptide mapping revealed similar patterns of phosphorylation of synprint polypeptides and native rat brain $\mathrm{N}$-type calcium channel $\alpha_{1 \mathrm{~B}}$ subunits by PKC and Cam KII. Phosphorylation of the synprint peptide with PKC or CaM KII, but not PKA or PKG, strongly inhibited binding of recom- binant syntaxin or SNAP-25, even at a level of free calcium (15 $\mu \mathrm{M})$ that stimulates maximal binding. In contrast, phosphorylation of syntaxin and SNAP-25 with PKC and CaM KII did not affect interactions with the synprint site. Binding assays with polypeptides representing the $\mathrm{N}$ - and $\mathrm{C}$-terminal halves of the synprint site indicate that the PKC- and CaM KII-mediated inhibition of binding involves multiple, disperse phosphorylation sites. PKC or CaM KII phosphorylation of the synprint peptide also inhibited its interactions with native rat brain SNARE complexes containing syntaxin and SNAP-25. These results suggest that phosphorylation of the synprint site by PKC or CaM KII may serve as a biochemical switch for interactions between $\mathrm{N}$-type calcium channels and SNARE protein complexes.

Key words: N-type calcium channel; synprint site; protein kinase C; $\mathrm{Ca}^{2+} / \mathrm{CaM}$ kinase II; SNARE complex; syntaxin 1A; SNAP-25
Voltage-gated calcium channels are an essential element of fast stimulus-secretion coupling in presynaptic termini of central and peripheral neurons (for review, see Dunlap et al., 1995). In response to membrane depolarization, they produce a rapid and localized calcium signal that interacts with calcium sensors on the exocytotic apparatus to initiate vesicle fusion and neurotransmitter release (Zucker, 1996). Numerous electrophysiological studies implicate N-type and P/Q-type calcium channels in the control of exocytosis (Hirning et al., 1988; Luebke et al., 1993; Wheeler et al., 1994; Reuter, 1995), and these calcium channel types are localized at high density in presynaptic terminals of central neurons (Westenbroek et al., 1992, 1995). Biochemical experiments demonstrate that both $\mathrm{N}$ - and $\mathrm{P} / \mathrm{Q}$-type calcium channels are complexed with proteins of the exocytotic apparatus, including the plasma membrane proteins syntaxin and synaptosomal protein of $25 \mathrm{kDa}$ (SNAP-25), and the vesicle membrane protein synaptotagmin (Bennett et al., 1992; Leveque et al., 1992, 1994; Yoshida et al., 1992; Martin-Moutot et al., 1996). Syntaxin,

\footnotetext{
Received April 28, 1997; revised July 2, 1997; accepted July 7, 1997.

This research was supported by a National Research Service Award from National Institutes of Health Training Grant T32 GM07108-19 to C.T.Y., a postdoctora research fellowship from the National Institute of Mental Health to Z.-H.S., and National Institutes of Health Research Grant NS22625 to W.A.C. We thank the following for their generous gifts: Eric Rotman for PKA, Brian Murphy for PKC, Debra Brickey and Tom Soderling for CaM KII and calmodulin, and Masami Takahashi for the $10 \mathrm{H} 5$ antibody. Carl Baker and Andrew Perdichizzi provided valuable technical advice and support.

Correspondence should be addressed to William A. Catterall, Department of Pharmacology, Box 357280, University of Washington, Seattle, WA 98195-7280.

Dr. Sheng's present address: Synaptic Functions Unit, National Institute of Neurological Disorders and Stroke, National Institutes of Health, Bethesda, MD 20892 Copyright (C) 1997 Society for Neuroscience $0270-6474 / 97 / 176929-10 \$ 05.00 / 0$
}

SNAP-25, and the vesicle membrane protein synaptobrevin together comprise the soluble $N$-ethylmaleimide-sensitive attachment factor receptor (SNARE) complex, a stable, coiled-coil heterotrimer that links the vesicle to the plasma membrane and forms a scaffold for other proteins and small molecules participating in exocytosis (Sollner et al., 1993a,b; Chapman et al., 1994).

Molecular cloning and expression of cDNA encoding the $\alpha_{1}$ subunits of $\mathrm{N}$ - and $\mathrm{P} / \mathrm{Q}$-type calcium channels allow a closer examination of these binding interactions (Mori et al., 1991; Starr et al., 1991; Dubel et al., 1992). The synaptic protein interaction (synprint) site in the intracellular loop II-III ( $\left.\mathrm{L}_{\mathrm{II}-\mathrm{III}}\right)$ of the $\alpha_{1 \mathrm{~B}}$ subunit binds to syntaxin and SNAP-25 (Sheng et al., 1994, 1996). Calcium has a biphasic effect on these interactions, stimulating optimal binding in the range of 10-30 $\mu \mathrm{M}$ and inhibiting binding at higher concentrations (Sheng et al., 1996). Furthermore, synprint peptides inhibit the fast, synchronous phase of neurotransmitter release in cultured sympathetic neurons (Mochida et al., 1996). Analogous synprint sites with different properties reside in $\mathrm{L}_{\text {II-III }}$ of the rbA and BI isoforms of $\alpha_{1 \mathrm{~A}}$ subunits from P/Q-type calcium channels (Rettig et al., 1996). Together, these studies suggest that presynaptic calcium channels not only provide the calcium signal required by the exocytotic apparatus, but they also contain structural elements that are integral to vesicle docking, priming, and fusion.

Second-messenger regulation of neurotransmitter release via modulation of the interactions of proteins with the exocytotic apparatus has a potentially important role in synaptic plasticity (Sudhof, 1995). Second messenger-activated protein kinases 
(PKs) expressed in presynaptic terminals include calcium and calmodulin-dependent PK type II (CaM KII), PKC, PKA, and PKG. Both N-type calcium channels and SNARE proteins are phosphorylated by one or more of these PKs (Ahlijanian et al., 1991; Hell et al., 1994; Hirling and Scheller, 1996; Shimazaki et al., 1996). Although one functional consequence of phosphorylation of voltage-gated ion channels is the modulation of channel gating (Catterall, 1994; Levitan, 1994), the functional role of the synprint site in synaptic transmission suggests that this interaction site may also be modulated by phosphorylation. In this study, we characterize phosphorylation of the $\alpha_{1 \mathrm{~B}}$ synprint site and show that it regulates the ability of the synprint site to interact with syntaxin $1 \mathrm{~A}$ and SNAP-25.

\section{MATERIALS AND METHODS}

Preparation of fusion proteins. Recombinant DNA segments encoding the synprint region from the rat N-type calcium channel $\alpha_{1 \mathrm{~B}}$ subunit, designated $\alpha_{1 \mathrm{~B}}(718-859), \alpha_{1 \mathrm{~B}}(832-963)$, and $\alpha_{1 \mathrm{~B}}(718-963)$, were subcloned into the bacterial expression vector pTrcHis C (Invitrogen, San Diego, CA) as described (Sheng et al., 1994). Recombinant rat cDNA for both syntaxin 1A and SNAP-25 were subcloned into the pGEX-4T bacterial expression vector (Pharmacia, Piscataway, NJ) as described (Sheng et al., 1994, 1996; Rettig et al., 1996). Fusion protein cDNAs were transformed and expressed using standard procedures in the protease-deficient BL-26 strain of Escherichia coli (Novagen, Madison, WI). For the large-scale production of fusion proteins, $10 \mathrm{ml}$ cultures of transformed BL-26 were grown in Luria-Bertani medium supplemented with $100 \mu \mathrm{g} / \mathrm{ml}$ ampicillin for 12-16 hr and expanded to $500 \mathrm{ml}$ for $2 \mathrm{hr}$, followed by induction of fusion protein expression for $2 \mathrm{hr}$ with $0.2 \mathrm{~mm}$ isopropyl- $\beta$-D-thiogalactopyranoside. Cells were pelleted at $3000 \mathrm{rpm}$ in a Beckman J-6B centrifuge with a JS-4.2 rotor, resuspended in $10 \mathrm{ml}$ PBS $(10 \mathrm{~mm}$ $\mathrm{Na}_{2} \mathrm{HPO}_{4}, \mathrm{pH} 7.4,150 \mathrm{~mm} \mathrm{NaCl}$ ) with the protease inhibitors phenylmethanesulfonyl fluoride (PMSF) $(0.4 \mu \mathrm{M})$ and pepstatin A $(4 \mu \mathrm{g} / \mathrm{ml})$, and sonicated. Extracts were immediately solubilized with Triton X-100 (TX-100) at $1 \%$ and $N$-lauroyl sarkosine at $0.5 \%$ and incubated for 20 min on ice, and the unsolubilized material was removed by centrif ugation at $10,000 \mathrm{rpm}$ for $10 \mathrm{~min}$ in a Beckman J2-21 centrifuge with a JA-20 rotor. The amount of glutathione-S-transferase (GST) fusion protein in the cleared lysate was estimated by Coomassie blue staining after SDSPAGE using an albumin standard curve.

Purification of his-tagged fusion proteins. His-tagged fusion proteins were affinity-purified by $\mathrm{Ni}^{2+}$-nitrilotriacetic acid (NTA) agarose chromatography (Qiagen, Chatsworth, CA) with chromatographic conditions adapted from the manufacturer. The percentage of detergent in the extract was reduced by concentrating the extract to 0.1 volumes by centrifugation at $2500 \mathrm{rpm}$ for $1 \mathrm{hr}$ in a centriprep-10 filtration unit (Amicon, Beverly, MA), and the original volume was reconstituted with PBS containing $0.4 \mu \mathrm{M}$ PMSF and $4 \mu \mathrm{g} / \mathrm{ml}$ pepstatin A, which were included in all subsequent wash buffers. $\mathrm{Ni}^{2+}$-NTA agarose resin $(2 \mathrm{ml})$ was washed three times with PBS and incubated with the extract for $1 \mathrm{hr}$ at $4^{\circ} \mathrm{C}$ with continuous mixing. The resin was loaded into a $1.6-\mathrm{cm}-$ diameter column and washed with PBS at a rate of $0.5 \mathrm{ml} / \mathrm{min}$ until the $\mathrm{A}_{280}$ of the flow-through was $<0.01$. The resin was further washed with PBS with $20 \mathrm{~mm}$ imidazole and $1 \%$ glycerol until the $\mathrm{A}_{280}$ of the flow-through was again $<0.01$, and the bound proteins were eluted with $30 \mathrm{ml}$ PBS containing $500 \mathrm{~mm}$ imidazole. The purified his-tagged fusion proteins were concentrated to $1 \mathrm{ml}$ by centrifugation for $1 \mathrm{hr}$ at $2500 \mathrm{rpm}$ in a centriprep-10, and dialyzed against a buffer of $20 \mathrm{~mm}$ Tris- $\mathrm{HCl}, \mathrm{pH}$ 7.4, $200 \mathrm{~mm} \mathrm{NaCl}$ for $16-24 \mathrm{hr}$ at $4^{\circ} \mathrm{C}$ in a 10,000 molecular weight cut-off cassette (Pierce, Rockford, IL). Purified his-tagged fusion proteins were quantitated by the bicinchoninic acid assay (Pierce), and polypeptide purity and integrity were verified by SDS-PAGE followed by Coomassie blue staining.

Phosphorylation. Phosphorylation reactions were performed with 15 pmol of synprint polypeptide in a basal buffer containing $50 \mathrm{mM}$ HEPES$\mathrm{NaOH}, \mathrm{pH} 7.4,1 \mathrm{~mm}$ dithiothreitol (DTT), $10 \mathrm{~mm} \mathrm{MgCl}_{2}, 0.4 \mathrm{~mm}$ ATP (Sigma, St. Louis, MO), and purified PK supplemented with kinasespecific activators, when necessary (Yokoyama et al., 1995). Phosphorylation with the cAMP-dependent PK used $1.0 \mu \mathrm{g}$ of a rabbit skeletal muscle preparation of the catalytic subunit, purified as described (Kaczmarek et al., 1980), whereas $0.1 \mu \mathrm{g}$ cGMP-dependent PK (Promega, Madison, WI) was added to each reaction along with $2 \mu \mathrm{M}$ cGMP.
Reactions with $1.0 \mu \mathrm{g}$ purified PKC (Woodgett and Hunter, 1987) were supplemented with $1.5 \mathrm{mM} \mathrm{CaCl}_{2}, 1 \mathrm{~mm}$ EGTA, $50 \mu \mathrm{g}$ diolein $(1,2-$ dioleoyl-sn-glycerol) [C18:1, (cis)-9] (Sigma), and $2.5 \mathrm{mg} \mathrm{L-} \alpha$ phosphatidylserine (Avanti Polar Lipids, Alabaster, AL), whereas $2 \mathrm{~mm}$ $\mathrm{CaCl}_{2}$ and $1.9 \mu \mathrm{M}$ calmodulin were added to reactions with $0.5 \mu \mathrm{g}$ baculovirus-expressed and purified recombinant CaM kinase II $\alpha$ subunit (Brickey et al., 1990). Reactions proceeded for $1 \mathrm{hr}$ at $32^{\circ} \mathrm{C}$ and were either used immediately for in vitro binding assays or stored at $-20^{\circ} \mathrm{C}$ for subsequent use. Phosphorylation of immunoprecipitated native rat brain $\mathrm{N}$-type calcium channel $\alpha_{1 \mathrm{~B}}$ subunits was performed as described previously (Yokoyama et al., 1995), except with incubation for $1 \mathrm{hr}$ to insure complete phosphorylation.

Stoichiometry. For phosphorylation time course experiments, $15 \mathrm{pmol}$ of synprint polypeptide, in the phosphorylation buffers described above, was supplemented with $0.4 \mu \mathrm{M} \gamma^{32} \mathrm{P}$-ATP (DuPont NEN, Boston, MA) and incubated at $32^{\circ} \mathrm{C}$. Additional $\gamma^{32} \mathrm{P}$-ATP and kinase were added to time course reactions at $240 \mathrm{~min}$ to test whether these reagents were limiting maximal incorporation. Reactions were terminated by the addition of boiling SDS sample buffer. After SDS-PAGE, gel drying, and autoradiography, relevant gel slices were excised and Cerenkov-counted to determine total ${ }^{32} \mathrm{P}$ incorporation. Nonspecific contributions from background $\gamma^{32} \mathrm{P}$-ATP in the gel were eliminated by subtraction of the $\mathrm{cpm}$ in control gel slices excised from each lane. Specific radioactivity per mole of $\gamma^{32}$ P-ATP was determined by counting diluted aliquots of the stock, and this conversion value was used to calculate moles of ${ }^{32} \mathrm{P}$ incorporated and the molar ratio of ${ }^{32} \mathrm{P}$ to synprint polypeptide.

Two-dimensional phosphopeptide analysis. Two-dimensional phosphopeptide mapping was performed as outlined previously (Murphy and Catterall, 1992). Briefly, phosphoproteins were separated by SDS-PAGE and identified in the wet gel by autoradiography; the corresponding gel slices were excised. Gel slices were washed in $10 \%$ acetic acid, $10 \%$ isopropanol (v/v) for $16 \mathrm{hr}$, and then washed two times for $1.5 \mathrm{hr}$ in $50 \%$ methanol (v/v), dried in a Speed Vac concentrator (Savant, Holbrook, NY), and rehydrated in $1 \mathrm{ml}$ of $25 \mathrm{~mm}$ ammonium bicarbonate. Proteins were digested with $50 \mu \mathrm{g}$ of tosyl-amido 2-phenylethyl chloromethyl ketone (TPCK)-treated trypsin (Worthington Biochemical, Freehold, $\mathrm{NJ})$ for $16 \mathrm{hr}$ at $37^{\circ} \mathrm{C}$, followed by an additional extraction with $25 \mathrm{~mm}$ ammonium bicarbonate for $2 \mathrm{hr}$. Peptides in the pooled supernatants were washed extensively with $\mathrm{H}_{2} \mathrm{O}$, resuspended in $1 \%$ ammonium carbonate, $\mathrm{pH} 8.9$, and spotted on thin layer cellulose plates (Kodak, Rochester, NY). Phosphopeptides were separated in the first dimension by electrophoresis at $400 \mathrm{~V}$ in a $1 \%$ ammonium carbonate buffer system, $\mathrm{pH} 8.9$, and in the second dimension by ascending chromatography in pyridine/acetic acid/butanol/water (15:10:3:12), and visualized by autoradiography.

Binding assays. Twenty-five microliters of a $75 \%(\mathrm{v} / \mathrm{v})$ glutathioneSepharose 4B slurry (Pharmacia) were washed three times with TBS (10 $\mathrm{mm}$ Tris- $\mathrm{HCl}, \mathrm{pH} 7.4,150 \mathrm{~mm} \mathrm{NaCl}$ ) and $0.1 \% \mathrm{TX}-100$, reconstituted to $1 \mathrm{ml}$ with TBS, and incubated with $50 \mathrm{pmol}$ of GST fusion protein for 1 hr at $4^{\circ} \mathrm{C}$ on a microtube rotator. Samples were washed three times with TBS containing $0.1 \%$ TX-100 and reconstituted to $1 \mathrm{ml}$ with the same buffer. His-tagged fusion protein $(7-30 \mathrm{pmol})$ was added, and the samples were incubated an additional $3 \mathrm{hr}$, followed by 3 washes with TBS $/ 0.1 \%$ TX-100, elution of the bound protein complexes, and analysis by SDS-PAGE as described below.

For experiments at different calcium concentrations, the buffer used in the last wash after the initial GST fusion protein incubation as well as the subsequent his-tagged incubation buffer and wash buffer were replaced with solutions containing $N$-(2-hydroxyethyl) EDTA (H-EDTA) (Sigma)-buffered calcium at fixed concentrations determined by the MaxChelator software (Chris Patton, Stanford University, Hopkins Marine Station, Pacific Grove, CA; version 6.81) prepared as described (Sheng et al., 1996). For experiments involving the phosphorylation of GST fusion proteins, the kinase reaction mixtures described in the phosphorylation section were added directly to the immobilized GST fusion proteins after the initial binding incubation and washes. After the phosphorylation step, the resin was washed three times with $\mathrm{TBS} / 0.1 \% \mathrm{TX}-100$, and incubation with the his-tagged fusion proteins proceeded as described above. For protein complexes immobilized on protein A-Sepharose CL-4B by immunoprecipitation, as described in the immunoprecipitation section, the samples were washed three times with TBS/0.1\% TX-100, and the incubation with the his-tagged fusion proteins proceeded as described above.

Immunoprecipitation. Rat brain synaptosomes were prepared by differential and discontinuous Ficoll gradient centrifugation and solubilized as 
described (Sheng et al., 1996). Solubilized synaptosome protein (300$400 \mu \mathrm{g}$ ) was incubated with $10 \mu \mathrm{g}$ of $10 \mathrm{H} 5$, an anti-syntaxin mouse monoclonal antibody (Yoshida et al., 1992), or control mouse IgG (Zymed, San Francisco, CA) in $1 \mathrm{ml}$ TBS with 1\% TX-100, 0.1\% BSA, and the protease inhibitors PMSF $(0.4 \mu \mathrm{M})$ and pepstatin A, benzamidine, leupeptin, and aprotinin (each at $4 \mu \mathrm{g} / \mathrm{ml}$ ), and incubated on a microtube rotator at $4^{\circ} \mathrm{C}$ for $1 \mathrm{hr}$. Protein A-Sepharose CL-4B resin $(2.5$ $\mathrm{mg}$ ) (Pharmacia), prewashed three times in incubation buffer, was added to each sample, and the incubation continued for an additional $2 \mathrm{hr}$, followed by three washes with TBS/0.1\% TX-100. Subsequent interaction assays of immunoprecipitated and immobilized protein complexes with his-tagged fusion proteins are described in the section on binding assays above. Immunoprecipitation of native rat $\mathrm{N}$-type calcium channel $\alpha_{1 \mathrm{~B}}$ subunits from brain extracts enriched for calcium channels by wheat germ agglutinin-Sepharose chromatography was performed as described previously (Yokoyama et al., 1995), except that $10 \mu \mathrm{g}$ of CNB1 anti-peptide antibody (Westenbroek et al., 1992) was used.

$S D S-P A G E$. Fusion protein complexes immobilized on glutathioneSepharose 4B were suspended in $20 \mathrm{ml}$ elution buffer (Tris-HCl, $\mathrm{pH} 8.0$, $15 \mathrm{~mm}$ reduced glutathione) and incubated on a vortex mixer for $20 \mathrm{~min}$. After centrifugation, the eluted fusion protein complexes in the supernatant were denatured and reduced in SDS sample buffer $(50 \mathrm{~mm} 0.5 \mathrm{M}$ Tris- $\mathrm{HCl}, \mathrm{pH} 8.45,12 \%$ glycerol, $4 \%$ SDS, $0.015 \%$ Coomassie blue $\mathrm{G}$ ) containing $50 \mathrm{~mm} \mathrm{DTT}$, and heated at $95^{\circ} \mathrm{C}$ for $5 \mathrm{~min}$. For experiments in which immunoprecipitation was performed, protein complexes on protein A-Sepharose CL-4B were directly denatured in SDS sample buffer. For $\gamma^{32} \mathrm{P}$-ATP incorporation experiments, phosphorylation reactions were terminated with the addition of SDS sample buffer. Denatured and reduced proteins were separated on a discontinuous SDSpolyacrylamide gel (separation gel: $16.5 \%$ total acrylamide, $1 \%$ bisacrylamide; stacking gel: $4 \%$ total acrylamide, $0.25 \%$ bis-acrylamide) in a Tris-Tricine buffer system along with prestained molecular weight markers (Life Technologies-BRL, Grand Island, NY). Separated proteins were visualized by Coomassie blue staining, and ${ }^{32} \mathrm{P}$ incorporation was measured by autoradiography for $1 \mathrm{hr}$ on hyperfilm (Amersham, Arlington Heights, IL), or the separated proteins were electrophoretically transferred to nitrocellulose filters for immunoblotting. For twodimensional phosphopeptide analysis, immunoprecipitated rat $\mathrm{N}$-type calcium channel $\alpha_{1 \mathrm{~B}}$ subunits were separated on a $3 \%$ stacking gel and a $5 \%$ separating gel in a Laemmli Tris-glycine buffer system (Yokoyama et al., 1995), whereas fusion polypeptides were separated on a large-pore $12 \%$ modified Laemmli gel (Doucet et al., 1990).

Immunoblotting. Nitrocellulose filters $(0.2 \mu \mathrm{m}$ pore size) (Schleicher \& Schuell, Keene, $\mathrm{NH}$ ) were incubated in a blocking solution of TBS (10 $\mathrm{mm}$ Tris- $\mathrm{HCl}, \mathrm{pH} 8.0,150 \mathrm{~mm} \mathrm{NaCl}$ ) containing $0.1 \%$ Tween-20 and $10 \%$ nonfat dry milk. His-tagged fusion proteins were labeled by incubation with $100 \mathrm{ng} / \mu \mathrm{l}$ T7-Tag mouse monoclonal antibody (Novagen), washed $2 \times 5 \mathrm{~min}$, and labeled with a 1:10,000 dilution of an anti-mouse $\mathrm{IgG}$ antibody conjugated to horseradish peroxidase (Amersham), followed by $3 \times 20$ min washes. Membranes were then saturated with reagents for enhanced chemiluminescence detection of horseradish peroxidase complexes (Amersham) and exposed on autoradiographic hyperfilm (Amersham). TBS containing 0.1\% Tween-20 was used for the primary and secondary incubations, and all washes were performed at room temperature for $1 \mathrm{hr}$ with gentle platform rotation. Native rat syntaxin was labeled with $10 \mathrm{ng} / \mu \mathrm{l} 10 \mathrm{H} 5$, a mouse monoclonal antibody (Yoshida et al., 1992), and native rat SNAP-25 was labeled with $250 \mathrm{ng} / \mu \mathrm{l}$ of a mouse anti-peptide antibody against mouse SNAP-25 (Transduction Laboratories, Lexington, KY). Secondary labeling of $10 \mathrm{H} 5$ was performed as described for the T7-Tag antibody, and labeling of the antiSNAP-25 antibody used a 1:2000 dilution of a peroxidase-coupled, $\mathrm{IgG}_{1}$ specific anti-mouse IgG (Zymed).

For detection of GST fusion proteins, blots exposed to T7-Tag antibody complexes were first stripped in a solution of $62.5 \mathrm{~mm}$ Tris- $\mathrm{HCl}, \mathrm{pH}$ 6.7, $20 \mathrm{~mm}$ DTT, and $1 \% \mathrm{SDS}$ for $30 \mathrm{~min}$ at $50^{\circ} \mathrm{C}$ with agitation, washed with TBS $/ 0.5 \%$ Tween- 20 for $2 \times 15$ min, and reblocked with the same solution containing $10 \%$ nonfat dry milk. For anti-GST immunoblotting, TBS containing $0.1 \%$ Tween- 20 and $10 \%$ nonfat dry milk was used for all steps except the final washes, which omitted the milk. Primary labeling was performed using a 1:500 dilution of a goat anti-GST antiserum (Pharmacia) followed by $2 \times 5$ min washes. Secondary labeling was performed with a 1:5000 dilution of a monoclonal anti-goat IgG biotin conjugate (Sigma), followed by $2 \times 5$ min washes. Tertiary labeling was performed with a 1:2000 dilution of a streptavidin biotinylated-horse-
A.
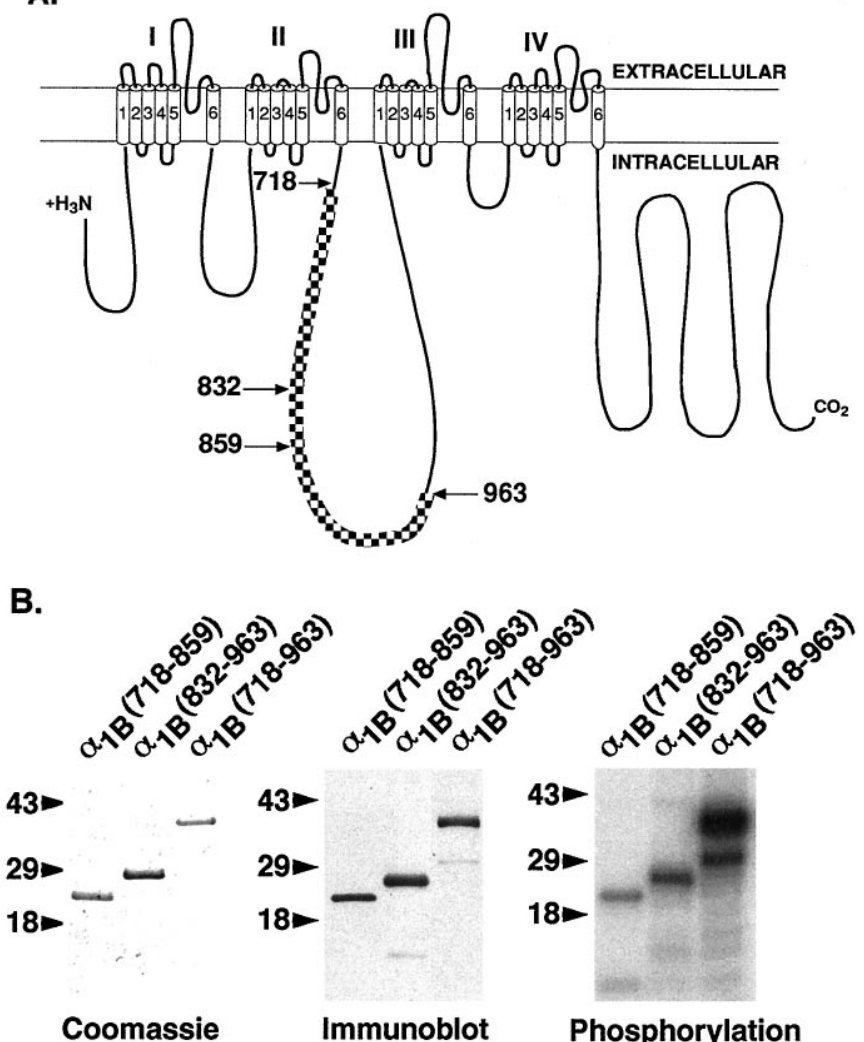

Figure 1. Synprint polypeptides are derived from the intracellular loop connecting homologous domains II and III $\left(\mathrm{L}_{\text {II-III }}\right)$ of the N-type calcium channel $\alpha_{1 \mathrm{~B}}$ subunit. $A$, Folding diagram of the $\mathrm{N}$-type calcium channel $\alpha_{1 \mathrm{~B}}$ subunit with the synprint site in $\mathrm{L}_{\mathrm{II}-\mathrm{III}}$ indicated by the checkered segment. Amino acid positions defining the full-length synprint $\left[\alpha_{1 \mathrm{~B}}(718-\right.$ $963)]$, the N-terminal half $\left[\alpha_{1 \mathrm{~B}}(718-859)\right]$, and the C-terminal half $\left[\alpha_{1 \mathrm{~B}}(832-963)\right]$ are indicated by the arrows. $B$, Purification and detection of synprint polypeptides. $\alpha_{1 \mathrm{~B}}(718-859), \alpha_{1 \mathrm{~B}}(832-963)$, and $\alpha_{1 \mathrm{~B}}(718-963)$ were expressed in $E$. coli, purified from detergent lysates by $\mathrm{Ni}^{2+}$-chelate chromatography, and analyzed by SDS-PAGE. One microgram of each polypeptide was visualized by Coomassie blue staining (left panel), or 0.1 $\mu \mathrm{g}$ of each was detected by immunoblotting with an anti-his-tag antibody (middle panel) or by PKC-dependent incorporation of ${ }^{32} \mathrm{P}$ followed by autoradiography (right panel).

radish peroxidase complex (Amersham), followed by $3 \times 20$ min washes and enhanced chemiluminescence detection.

\section{RESULTS}

\section{Purification of the $\alpha_{1 \mathrm{~B}}$ synprint site}

The his-tagged synprint site from the rat $\mathrm{N}$-type calcium channel $\alpha_{1 \mathrm{~B}}$ subunit is contained within amino acids 718-963 in $\mathrm{L}_{\text {II-III }}$ of the $\alpha_{1 \mathrm{~B}}$ subunit (Sheng et al., 1994; Rettig et al., 1996) (Fig. 1 $A$ ). Two smaller his-tagged fusion proteins that also interact with syntaxin and SNAP-25, spanning amino acids 718-859 and 832-963, define the $\mathrm{N}$ - and C-terminal halves of the $\alpha_{1 \mathrm{~B}}$ synprint site, with a 27 amino acid overlap (Sheng et al., 1994; Rettig et al., 1996) (Fig. 1A). All three his-tagged synprint polypeptides were expressed in $E$. coli, extracted by sonication and detergent solubilization, and purified by $\mathrm{Ni}^{2+}$ chelate chromatography. Coomassie blue staining of the isolated synprint polypeptides after SDS-PAGE confirmed the homogeneity of the preparation (Fig. 1B, left panel), with $\alpha_{1 \mathrm{~B}}(718-859), \alpha_{1 \mathrm{~B}}(832-963)$, and $\alpha_{1 \mathrm{~B}}(718-963)$ migrating at approximate molecular masses of 24,28 , and $36 \mathrm{kDa}$, respec- 
A. $\alpha_{1 \mathrm{~B}}(718-859)$
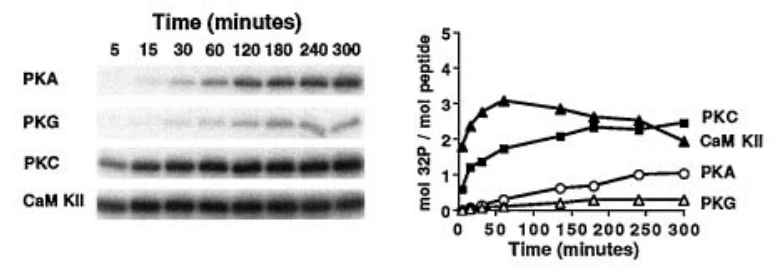

B. $\alpha_{1 \mathrm{~B}}(832-963)$
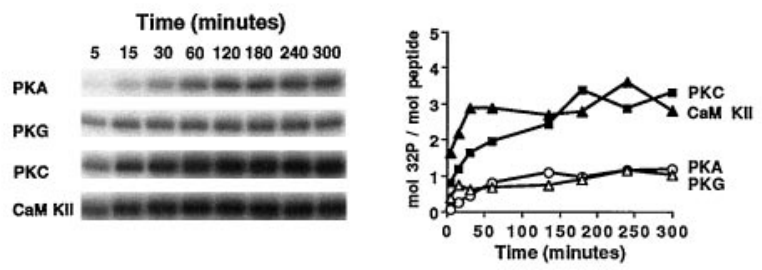

C. $\alpha_{1 \mathrm{~B}}(718-963)$
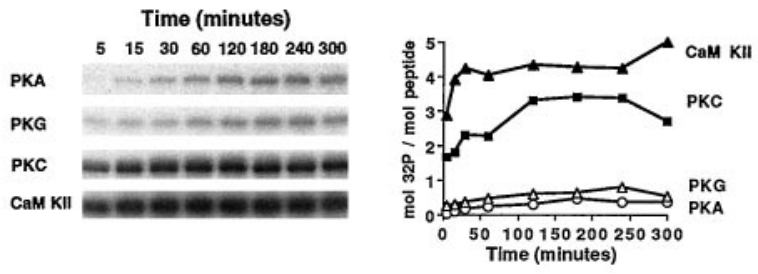

Figure 2. Stoichiometry of phosphorylation for synprint polypeptides. Polypeptides were phosphorylated with PKA (open circles), PKG (open triangles), PKC (closed squares), or CaM KII (closed triangles) for the indicated time periods. Reactions were terminated by the addition of SDS sample buffer, the products were separated by SDS-PAGE, and the gels were dried and exposed to film for $1 \mathrm{hr}$ (left panels). Gel slices containing labeled synprint polypeptides were excised and Cerenkov-counted, and the moles of ${ }^{32} \mathrm{P}$ incorporated per mole of synprint peptide were calculated and plotted as a function of time (right panels). A, Time course and stoichiometry of phosphorylation for $\alpha_{1 \mathrm{~B}}(718-859)$. $B$, Time course and stoichiometry of phosphorylation for $\alpha_{1 \mathrm{~B}}(832-963)$. $C$, Time course and stoichiometry of phosphorylation for $\alpha_{1 \mathrm{~B}}(718-963)$.

tively. Immunoblotting with an anti-his-tag monoclonal antibody recognizing the his-tag leader sequence confirmed the integrity of the full-length polypeptides (Fig. $1 B$, middle panel). Minor C-terminal proteolytic truncations are observed for $\alpha_{1 \mathrm{~B}}(832-963)$ and $\alpha_{1 \mathrm{~B}}(718-963)$, but relative densitometry measurements in the linear range of the detection system indicate that they account for $<5 \%$ of the full-length polypeptide in each preparation. For both $\alpha_{1 \mathrm{~B}}(832-963)$ and $\alpha_{1 \mathrm{~B}}(718-$ 963) the size of the minor proteolytic product is $10-12 \mathrm{kDa}$ smaller than the full-length polypeptide, suggesting a probable common proteolytic cleavage site. As an alternative assessment of polypeptide integrity, the his-tagged fusion proteins were phosphorylated with $\gamma^{32}$ P-ATP and PKC. SDS-PAGE followed by autoradiography demonstrated that the major PKC substrates in the preparations are the synprint polypeptides (Fig. $1 B$, right panel). Quantitation of ${ }^{32} \mathrm{P}$ by Cerenkov counting of excised gel slices for the full-length and proteolytic product of $\alpha_{1 \mathrm{~B}}(718-963)$ indicated that the lower band incorporated $<5 \%$ of the ${ }^{32} \mathrm{P}$ incorporated into the full-length $\alpha_{1 \mathrm{~B}}(718-963)$. Together, these results demonstrate the high purity of the synprint peptides and validate the use of an assay for total protein in these preparations to estimate the full-length peptide concentration.

\section{Phosphorylation of the $\alpha_{1 \mathrm{~B}}$ synprint site}

The synprint site polypeptides were tested as substrates for a panel of purified second-messenger activated PKs. Fifteen picomoles of purified $\alpha_{1 \mathrm{~B}}(718-963), \alpha_{1 \mathrm{~B}}(718-859)$, and $\alpha_{1 \mathrm{~B}}(832-963)$ were incubated with $\gamma^{32} \mathrm{P}$-ATP and either PKA, PKG, PKC, or CaM KII, with cognate activators. Reactions were terminated with the addition of boiling SDS sample buffer, and the polypeptides were separated by SDS-PAGE, followed by autoradiography for $1 \mathrm{hr}$ (Fig. 2, left panels). For quantitation of incorporated ${ }^{32} \mathrm{P}$, gel slices corresponding to phosphorylated polypeptides were excised and Cerenkov-counted. Stoichiometry values are expressed as the ratio of moles of ${ }^{32} \mathrm{P}$ incorporated per mole of synprint polypeptide and plotted against reaction time (Fig. 2, right panels). Control experiments with a panel of unrelated his-tagged polypeptides showed that none of the kinases that were tested phosphorylated the his-tag leader sequence (C. T. Yokoyama and W. A. Catterall, unpublished observations). The synprint $\alpha_{1 \mathrm{~B}}(718-963)$ was a poor substrate for PKA and PKG, with maximal stoichiometry of $\sim 0.3$ and 0.5 , respectively (Fig. $2 C)$. In contrast, $\alpha_{1 \mathrm{~B}}(718-963)$ was a good substrate for phosphorylation by $\mathrm{PKC}$ and $\mathrm{CaM}$ KII, with maximal stoichiometries of $\sim 3.0$ and 4.0. Even with the addition of extra $\gamma^{32} \mathrm{P}-\mathrm{ATP}$ and kinase at $240 \mathrm{~min}$, there is little or no increase in the maximal stoichiometry, demonstrating that those reagents did not limit the maximal ${ }^{32} \mathrm{P}$ incorporation. Approximate stoichiometry for phosphorylation of the N-terminal half of the synprint (Fig. $2 A$ ), $\alpha_{1 \mathrm{~B}}(718-859)$, was 0.9 for PKA, 0.2 for PKG, 2.0 for PKC, and 3.0 for CaM KII. Similarly, the stoichiometry of phosphorylation for the C-terminal half of the synprint (Fig. 2B), $\alpha_{1 \mathrm{~B}}(832-963)$, was 0.8 for PKA, 0.8 for PKG, 3.0 for PKC, and 3.0 for CaM KII. The results reveal a trend shared by all three synprint polypeptides: phosphorylation by PKC and CaM KII to a stoichiometry of 2.0-4.0 within $30 \mathrm{~min}$, and phosphorylation by PKA and PKG to stoichiometries of $<1.0$, even at $5 \mathrm{hr}$. Although correlation of stoichiometry measurements with the precise number of phosphorylated residues is not possible from this analysis, there are clearly multiple good substrate sites for both PKC and CaM KII in both the $\mathrm{N}$ - and $\mathrm{C}$-terminal halves of the synprint peptide. In contrast, there is probably no more than one poor substrate site for PKA and PKG in the synprint peptide. The higher stoichiometry of phosphorylation of $\alpha_{1 \mathrm{~B}}(718-963)$ by PKC and CaM KII compared with its $\mathrm{N}$ - and $\mathrm{C}$-terminal halves suggests that phosphorylation of $\alpha_{1 \mathrm{~B}}(718-963)$ is the summation of phosphorylated substrate sites in each half. The higher stoichiometry of phosphorylation, however, for both $\mathrm{N}$ - and $\mathrm{C}$-terminal halves of the synprint by PKA and for the C-terminal half by PKG, compared with the full-length synprint, indicate that conformational differences in the smaller polypeptides increase the access or affinity of PKA and PKG for their putative substrate site(s), or expose additional sites phosphorylated at substoichiometric ratios.

\section{Comparison of phosphorylation of the synprint site in fusion proteins and intact $\mathbf{N}$-type calcium channels}

Two-dimensional tryptic phosphopeptide mapping experiments were performed to assess whether CaM KII or PKC phosphorylation of the synprint fusion polypeptide was similar to that of the native rat brain $\mathrm{N}$-type calcium channel $\alpha_{1 \mathrm{~B}}$ subunit. For $\mathrm{CaM}$ KII or PKC, phosphorylation of the fusion protein $\alpha_{1 \mathrm{~B}}(718-963)$ and analysis by two-dimensional phosphopeptide mapping resulted in distinctive patterns of 6 and 10 phosphopeptides, respectively (Fig. $3 A, C$ ). The major phosphopeptides observed in phos- 


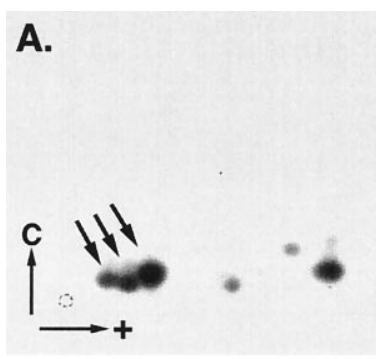

C.

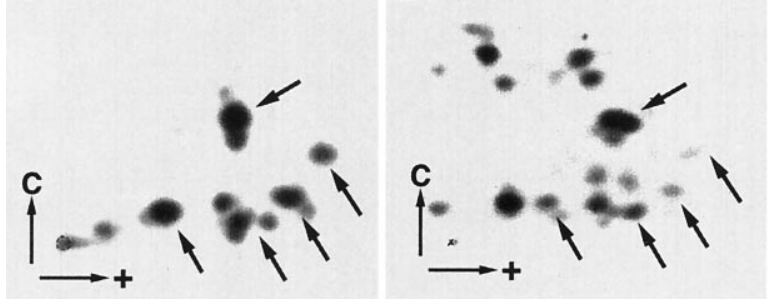

Figure 3. Two-dimensional tryptic phosphopeptide mapping of synprint polypeptides and native N-type calcium channel $\alpha_{1 \mathrm{~B}}$ subunits. Purified $\alpha_{1 \mathrm{~B}}(718-859)$ or immunoprecipitated $\mathrm{N}$-type calcium channel $\alpha_{1 \mathrm{~B}}$ subunits were phosphorylated in the presence of $\gamma^{32} \mathrm{P}$-ATP, separated by SDS-PAGE, located by autoradiography, and subjected to twodimensional phosphopeptide mapping as described in Materials and Methods. Tryptic phosphopeptides were resolved in two dimensions by electrophoresis $(+$, long arrow) followed by thin-layer chromatography $(C$, long arrow). $A$, CaM KII phosphorylation of $\alpha_{1 \mathrm{~B}}(718-963)$. $B$, CaM KII phosphorylation of native $\alpha_{1 \mathrm{~B}}$ subunit. $C$, PKC phosphorylation of $\alpha_{1 \mathrm{~B}}(718-963)$. D, PKC phosphorylation of native $\alpha_{1 \mathrm{~B}}$ subunit. Short arrows designate overlapping phosphopeptides between $A$ and $B$, or $C$ and $D$, respectively.

phorylation of $\alpha_{1 \mathrm{~B}}(718-963)$ are included as a subset of the more complex phosphopeptide map observed for the native N-type calcium channel protein isolated from rat brain (Fig. $3 B, D$ ). For Cam KII phosphorylation, a distinct triplet of phosphopeptides (Fig. 3A,B, arrows) is observed in both the fusion polypeptide and the native $\mathrm{N}$-type calcium channel subunit, whereas for PKC phosphorylation an overlapping spatial distribution of five phosphopeptides is observed (Fig. 3C,D, arrows). These results demonstrate that the phosphopeptides produced by phosphorylation of the synprint fusion protein are also phosphorylated in native $\alpha_{1 \mathrm{~B}}$ subunits.

\section{Effect of phosphorylation of the $\alpha_{1 \mathrm{~B}}$ synprint site on binding to syntaxin $1 A$ and SNAP-25}

The effect of phosphorylation on the binding properties of the $\alpha_{1 \mathrm{~B}}$ synprint site was determined in an interaction assay with recombinant, immobilized GST fusion proteins containing syntaxin 1A and SNAP-25. Protein complexes were separated by SDS-PAGE and transferred to nitrocellulose, and individual polypeptides were detected by Western blotting with anti-his-tag or anti-GSTtag antibodies. To detect potential bidirectional changes in binding, titration curves for the interaction of the $\alpha_{1 \mathrm{~B}}(718-963)$, $\alpha_{1 \mathrm{~B}}(718-859)$, and $\alpha_{1 \mathrm{~B}}(832-963)$ with immobilized syntaxin $1 \mathrm{~A}$ and SNAP-25 were generated to determine the linear range for binding of each protein, and these amounts [7-15 pmol for $\alpha_{1 \mathrm{~B}}(832-963)$ and $\alpha_{1 \mathrm{~B}}(718-963) ; 20-30 \mathrm{pmol}$ for $\left.\alpha_{1 \mathrm{~B}}(718-859)\right]$ were used in all subsequent experiments. PKA or PKG phosphorylation of $\alpha_{1 \mathrm{~B}}(718-963)$ for $60 \mathrm{~min}$ had no effect on binding to either GST-syntaxin 1A (60 kDa) or GST-SNAP-25 $(50 \mathrm{kDa})$, as measured by the invariant signal intensity on the immunoblot in the absence or presence of PKA (Fig. $4 A$ ) or PKG (Fig. $4 B$ )
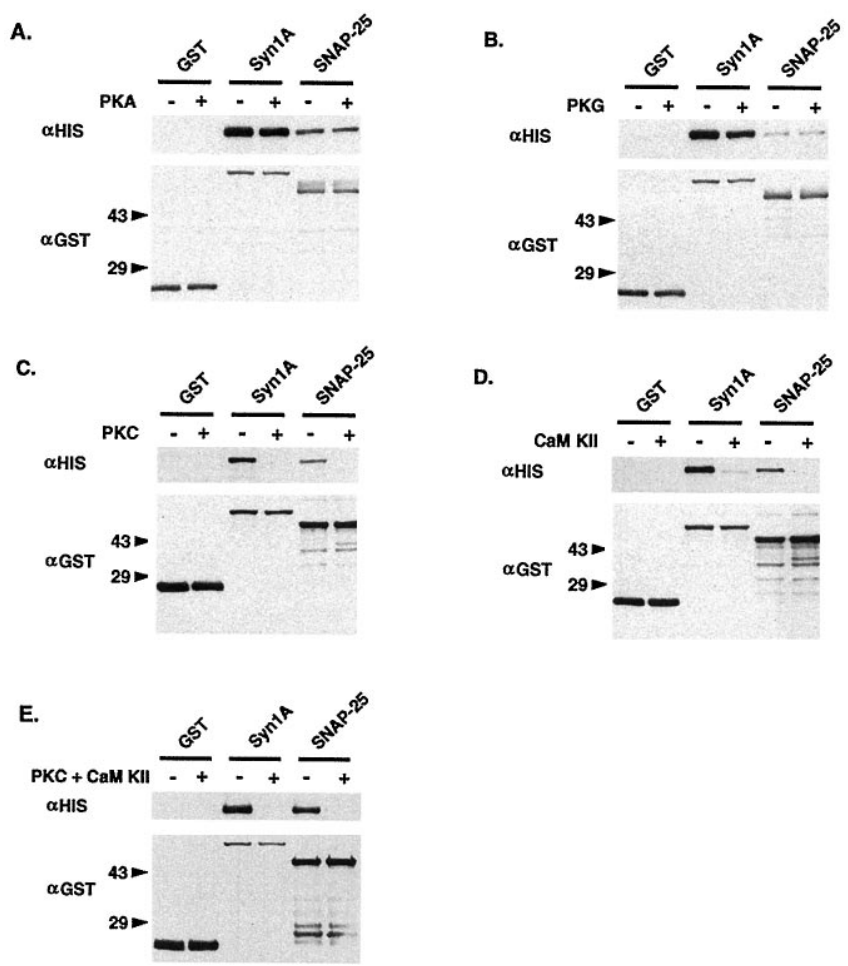

Figure 4. Effect of phosphorylation of synprint polypeptides on interactions with syntaxin and SNAP-25. Control GST, GST-syntaxin 1A, or GST-SNAP-25 were immobilized on glutathione-Sepharose and then incubated with $\alpha_{1 \mathrm{~B}}(718-963)$ phosphorylated with PKA, PKG, PKC, or CaM KII or were treated with a control buffer without kinase. Unbound reactants were removed by washing, and bound protein complexes were eluted from the matrix and separated by SDS-PAGE, electrophoretically transferred to nitrocellulose membranes, and immunoblotted with an anti-his-tag antibody. Membranes were then stripped and reprobed with an anti-GST antibody. $A$, Phosphorylation of $\alpha_{1 \mathrm{~B}}$ (718-963) with PKA $(+)$ or control buffer $(-)$ followed by binding to immobilized control GST $(25$ $\mathrm{kDa})$, GST-syntaxin 1A (60 kDa), or GST-SNAP-25 (50 kDa), and immunoblotting with an anti-his-tag antibody $(\alpha H I S)$ or anti-GST antibody $(\alpha G S T) . B$, PKG phosphorylation. $C$, PKC phosphorylation. $D$, $\mathrm{CaM}$ KII phosphorylation. $E$, Both PKC and CaM KII phosphorylation. Chemiluminescent signals for this and all subsequent experiments were within the linear range of the detection system.

treatment. No binding to a control GST protein $(25 \mathrm{kDa})$ was observed, and anti-GST-tag immunoblotting confirmed that the phosphorylation state of the synprint polypeptide did not interfere with the immobilization of the GST fusion proteins. In contrast to the results for PKA and PKG, PKC or CaM KII phosphorylation strongly inhibited the ability of $\alpha_{1 \mathrm{~B}}(718-963)$ to bind to syntaxin 1A and SNAP-25 (Fig. $4 C, D$ ). If $\alpha_{1 \mathrm{~B}}(718-963$ ) is phosphorylated by $\mathrm{PKC}$ and $\mathrm{CaM}$ KII together, binding to syntaxin 1A or SNAP-25 is also inhibited (Fig. 4E). Together, these results demonstrate that $\mathrm{PKC}$ or $\mathrm{CaM}$ KII phosphorylation, either alone or together, of residues in the synprint site inhibits interactions with syntaxin 1A and SNAP-25. Control experiments indicated that the inhibitory effect of PKC and CaM KII was dependent on both ATP and purified kinase, and also required the PKC activators calcium, L- $\alpha$-phosphatidylserine, and diolein, and the CaM KII activators calcium and calmodulin, respectively (C. T. Yokoyama and W. A. Catterall, unpublished observations), confirming that it is the kinase activity of the enzymes that is responsible for the inhibition of binding. 
A.

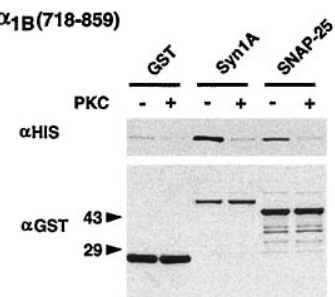

C. $\alpha_{1 B}(832-963)$

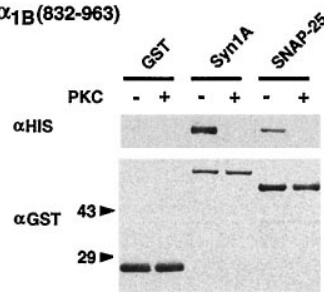

B. $\alpha_{1 \mathrm{~B}}(718-859)$

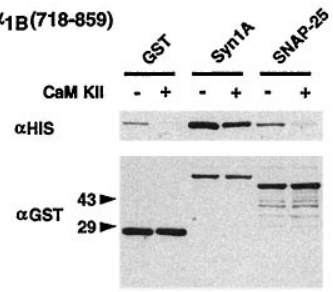

D. $\alpha_{1 \mathrm{~B}}(832-963)$

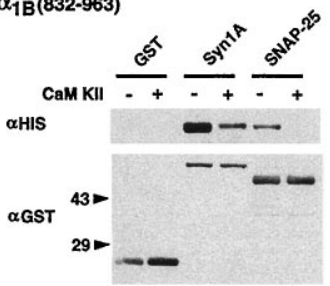

Figure 5. Effect of phosphorylation of the synprint N- and C-terminal halves on interactions with syntaxin and SNAP-25. Control GST, GSTsyntaxin 1A, or GST-SNAP-25 were immobilized on glutathioneSepharose and then incubated with either $\alpha_{1 \mathrm{~B}}(718-859)$ or $\alpha_{1 \mathrm{~B}}(832-963)$ phosphorylated with either PKC or CaM KII, or treated with a control buffer without kinase. Unbound reactants were removed by washing, and bound protein complexes were eluted from the matrix and separated by SDS-PAGE, electrophoretically transferred to nitrocellulose membranes, and immunoblotted with an anti-his-tag antibody. Membranes were then stripped and reprobed with an anti-GST antibody. $A$, Phosphorylation of $\alpha_{1 \mathrm{~B}}(718-859)$ with PKC $(+)$ or control buffer $(-)$ followed by binding to immobilized control GST $(25 \mathrm{kDa})$, GST-syntaxin 1A $(60 \mathrm{kDa})$, or GST-SNAP-25 (50 kDa), and immunoblotting with an anti-his-tag antibody $(\alpha H I S)$ or anti-GST antibody $(\alpha G S T)$. B, CaM KII phosphorylation of $\alpha_{1 \mathrm{~B}}(718-859)$. C, PKC phosphorylation of $\alpha_{1 \mathrm{~B}}(832-963) . D$, CaM KII phosphorylation of $\alpha_{1 \mathrm{~B}}(832-963)$.

\section{Effect of phosphorylation of the $\mathrm{N}$ - and $\mathrm{C}$-terminal halves of the $\alpha_{1 \mathrm{~B}}$ synprint peptide on binding to syntaxin $1 \mathrm{~A}$ and SNAP-25}

The $\mathrm{N}$ - and C-terminal halves of the $\alpha_{1 \mathrm{~B}}$ synprint peptide, $\alpha_{1 \mathrm{~B}}(718-859)$ and $\alpha_{1 \mathrm{~B}}(832-963)$, can each bind to syntaxin $1 \mathrm{~A}$ and SNAP-25 at a lower affinity than the full-length synprint site (Rettig et al., 1996). To investigate whether the PKC- and CaM KII-mediated inhibition of binding could be localized to either the $\mathrm{N}$ - or $\mathrm{C}$-terminal half of the $\alpha_{1 \mathrm{~B}}$ synprint site, we performed binding experiments with each half, in either the phosphorylated or unphosphorylated state, to immobilized GST-syntaxin 1A or GST-SNAP-25. PKC phosphorylation of $\alpha_{1 \mathrm{~B}}(718-859)$ inhibited binding to both syntaxin $1 \mathrm{~A}$ and SNAP-25 (Fig. $5 A$ ), whereas CaM KII phosphorylation inhibited SNAP-25 binding but did not significantly reduce syntaxin $1 \mathrm{~A}$ binding (Fig. $5 B$ ). Of the three synprint polypeptides tested here, $\alpha_{1 \mathrm{~B}}(718-859)$ has the weakest affinity for syntaxin 1A and SNAP-25 (Rettig et al., 1996) and a higher level of background binding to the control GST protein. $\mathrm{PKC}$ and $\mathrm{CaM}$ KII also reduced the nonspecific binding of $\alpha_{1 \mathrm{~B}}(718-859)$ to the control GST protein (Fig. $5 A, B$ ), indicating that phosphorylation altered structural or chemical determinants affecting both specific and nonspecific binding of this peptide. PKC phosphorylation of $\alpha_{1 \mathrm{~B}}(832-963)$ inhibited interactions with both syntaxin 1A and SNAP-25 (Fig. 5C). CaM KII inhibited binding to both syntaxin 1A and SNAP-25, although the inhibition of binding to syntaxin was incomplete (Fig. $5 D$ ). Evidently, PKC phosphorylation of either the $\mathrm{N}$ - or $\mathrm{C}$-terminal half of the synprint peptide disrupts interactions with syntaxin $1 \mathrm{~A}$ and SNAP-25. On the other hand, although CaM KII phosphorylation inhibits binding of each half of the synprint peptide to

\section{A. Syntaxin 1A}

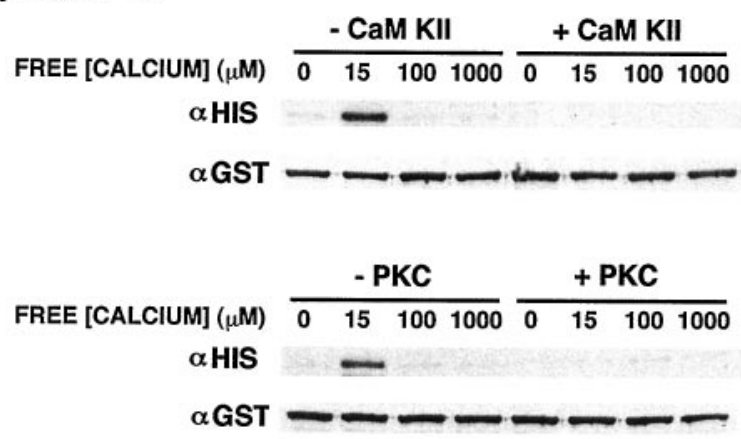

B. SNAP-25

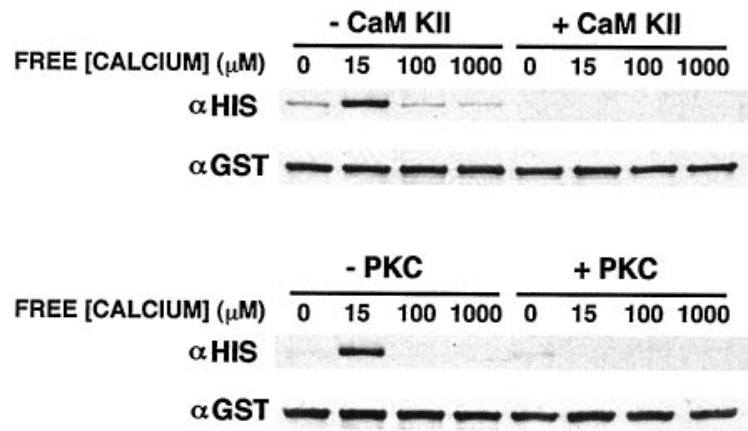

Figure 6. Effect of phosphorylation of synprint polypeptides on the calcium dependence of interactions with syntaxin and SNAP-25. GSTsyntaxin 1A or GST-SNAP-25 was immobilized on glutathione-Sepharose and then incubated with $\alpha_{1 \mathrm{~B}}(718-963)$ phosphorylated with either PKC or $\mathrm{CaM} \mathrm{KII}$, or treated with a control buffer without kinase. Incubations were performed in H-EDTA-buffered solutions calibrated to free calcium levels of $0,15,100$, or $1000 \mu \mathrm{M}$ calculated from the Max-Chelator software (v. 6.81). Unbound reactants were removed by washing, and bound protein complexes were eluted from the matrix and separated by SDS-PAGE, electrophoretically transferred to nitrocellulose membranes, and immunoblotted with an anti-his-tag antibody. Membranes were then stripped and reprobed with an anti-GST antibody. $A$, Phosphorylation of $\alpha_{1 \mathrm{~B}}(718-$ 963) with CaM KII (+) or control buffer $(-)$ (top half), or with PKC (+) or control buffer (-) (bottom half) followed by binding to immobilized GST-syntaxin 1A at free calcium concentrations of $0,15,100$, or $1000 \mu \mathrm{M}$, and immunoblotted with an anti-his-tag antibody $(\alpha H I S)$ or anti-GST antibody $(\alpha G S T)$. B, Binding to GST-SNAP-25.

SNAP-25, its inhibitory effect on binding to syntaxin is attenuated or absent. These results suggest differential regulation of the binding properties of the synprint site via PKC and CaM KII phosphorylation. The absence of consensus PKC or CaM KII phosphorylation sites in the 27 amino acid overlap shared by the two halves of the synprint peptide suggests that phosphorylation sites in both halves of the peptide are involved in the inhibition of binding.

\section{Effect of phosphorylation on the calcium-dependence of $\alpha_{1 \mathrm{~B}}$ synprint site binding to syntaxin 1A and SNAP-25}

The interaction of $\alpha_{1 \mathrm{~B}}(718-963)$ with either syntaxin 1A or SNAP-25 is stimulated by calcium in the $10-30 \mu \mathrm{M}$ range and inhibited by higher concentrations (Sheng et al., 1996). To examine whether phosphorylation alters the calcium dependence of binding or inhibits binding independent of calcium concentration, binding of $\alpha_{1 \mathrm{~B}}(718-963)$ to immobilized syntaxin 1A or SNAP-25 was assessed in solutions with H-EDTA- 
A.

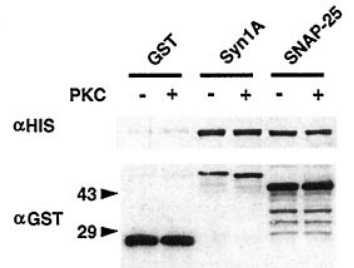

B.

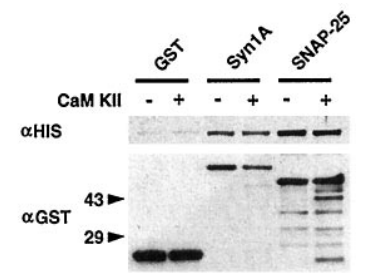

Figure 7. Effect of phosphorylation of syntaxin and SNAP-25 on interactions with synprint polypeptides. Control GST, GST-syntaxin 1A, or GST-SNAP-25 was immobilized on glutathione-Sepharose, phosphorylated with either PKC or CaM KII, or treated with a control buffer without kinase, and then incubated with $\alpha_{1 \mathrm{~B}}(718-963)$. Unbound reactants were removed by washing, and bound protein complexes were eluted from the matrix and separated by SDS-PAGE, electrophoretically transferred to nitrocellulose membranes, and immunoblotted with an anti-histag antibody. Membranes were then stripped and reprobed with an anti-GST antibody. $A$, Phosphorylation of control GST (25 kDa), GSTsyntaxin 1A $(60 \mathrm{kDa})$, and GST-SNAP-25 $(50 \mathrm{kDa})$ with PKC $(+)$ or a control buffer $(-)$, followed by incubation with $\alpha_{1 \mathrm{~B}}(718-963)$ and immunoblotting with an anti-his-tag antibody $(\alpha H I S)$ or anti-GST antibody $(\alpha G S T)$. B, Phosphorylation with CaM KII.

buffered free calcium levels. $\alpha_{1 \mathrm{~B}}(718-963)$ binds strongly to syntaxin $1 \mathrm{~A}$ at $15 \mu \mathrm{M}$ free calcium and more weakly at 0,100 , or $1000 \mu \mathrm{M}$ free calcium. Phosphorylation by either CaM KII or PKC inhibits binding at all levels of free calcium tested (Fig. $6 A)$. Similarly, $\alpha_{1 \mathrm{~B}}(718-963)$ binds to SNAP-25 most strongly at $15 \mu \mathrm{M}$ free calcium and more weakly at other concentrations. Phosphorylation by CaM KII or PKC inhibits the interaction at $0,15,100$, and $1000 \mu \mathrm{M}$ free calcium (Fig. 6B). Together, these results indicate that inhibition of binding by phosphorylation is dominant to calcium stimulation.

\section{Effect of phosphorylation of syntaxin 1A and SNAP-25 on binding to the $\alpha_{1 \mathrm{~B}}$ synprint site}

Syntaxin 1A and SNAP-25 are in vitro substrates for CaM KII (Hirling and Scheller, 1996), and SNAP-25 is phosphorylated by PKC in PC12 cells (Shimazaki et al., 1996). In contrast, PKA does not phosphorylate either syntaxin 1A or SNAP-25, and the effect of PKG is not known (Hirling and Scheller, 1996). To investigate whether phosphorylation of these proteins may have an effect on interactions with the $\alpha_{1 \mathrm{~B}}$ synprint site, immobilized GSTsyntaxin 1A and GST-SNAP-25 were phosphorylated by PKC or CaM KII, and their interactions with $\alpha_{1 \mathrm{~B}}(718-963)$ were assessed. Control experiments testing for the incorporation of ${ }^{32} \mathrm{P}$ into GST-syntaxin 1A, GST-SNAP-25, and a GST control protein indicated that although both GST-syntaxin 1A and GSTSNAP-25 were labeled by PKC or CaM KII, the GST moiety itself is not a substrate for phosphorylation by either kinase (C. T. Yokoyama and W. A. Catterall, unpublished observations). Phosphorylation of either syntaxin 1A or SNAP-25 with PKC had no effect on interactions with $\alpha_{1 \mathrm{~B}}(718-963)$, and control anti-GST immunoblotting showed that phosphorylation did not alter the interaction of the GST fusion proteins with the glutathioneSepharose matrix (Fig. 7A). CaM KII phosphorylation of syntaxin 1A and SNAP-25 also did not alter interactions with $\alpha_{1 \mathrm{~B}}(718-963)$ (Fig. 7B). In the absence of any effect of phosphorylation of syntaxin and SNAP-25 on interactions with the $\alpha_{1 \mathrm{~B}}(718-963)$, the phosphorylation site(s) required for PKC and CaM KII modulation are likely to reside exclusively within the $\alpha_{1 \mathrm{~B}}$ synprint site.

A.

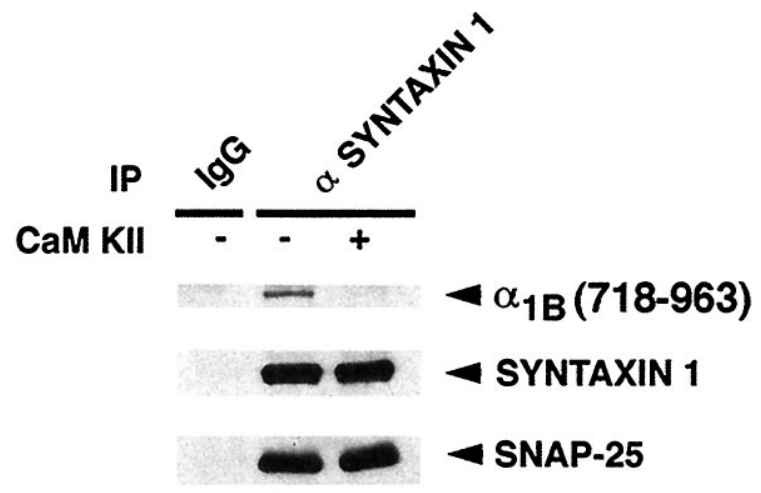

B.

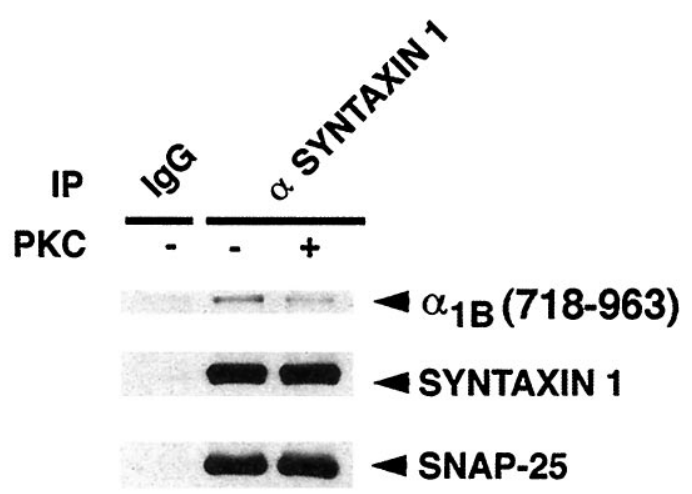

Figure 8. Effect of phosphorylation of synprint polypeptides on interactions with rat brain synaptosomal SNARE complexes. Rat brain synaptosomes were isolated by Ficoll gradient centrifugation and solubilized as described in Materials and Methods. Native SNARE complexes containing syntaxin and SNAP-25 were immunoprecipitated with an antisyntaxin antibody and captured on protein A-Sepharose. Nonspecific immunoprecipitation was assessed with a control mouse $\operatorname{IgG}$ antibody. After they were washed to remove unbound protein, the immobilized complexes were incubated with $\alpha_{1 \mathrm{~B}}(718-963)$ and phosphorylated with either CaM KII or PKC, or treated with a control buffer without kinase. Protein complexes were washed again, separated by SDS-PAGE, and electrophoretically transferred to a nitrocellulose filter. The filter was sectioned into three parts for immunoblotting with antibodies against the his-tag of $\alpha_{1 \mathrm{~B}}(718-963)$, syntaxin 1 , and SNAP-25. $A, \alpha_{1 \mathrm{~B}}(718-963)$ phosphorylated with CaM KII (+) or a control buffer without kinase (-) was added to SNARE complexes immunoprecipitated with an antisyntaxin 1 antibody ( $\alpha$ SYNTAXIN 1) or a control mouse IgG antibody $(I g G)$, and immunoblotted with anti-his-tag, anti-syntaxin 1, and antiSNAP-25 antibodies, as described in Materials and Methods. B, PKC phosphorylation of $\alpha_{1 \mathrm{~B}}(718-963)$.

\section{Effect of phosphorylation of the $\alpha_{1 \mathrm{~B}}$ synprint site on binding to native synaptosomal SNARE complexes}

To independently confirm the observations with recombinant fusion proteins, we assessed the ability of $\alpha_{1 \mathrm{~B}}(718-963)$, phosphorylated by PKC or CaM KII, to interact with native SNARE complexes containing syntaxin and SNAP-25 immunoprecipitated from rat brain synaptosomes. The anti-syntaxin 1 mouse monoclonal antibody 10H5 (Yoshida et al., 1992) was used to immunoprecipitate SNARE complexes from solubilized rat brain synaptosomes. After capture on protein A-Sepharose, complexes were incubated with either phosphorylated or unphosphorylated $\alpha_{1 \mathrm{~B}}(718-963)$ and subjected to SDS-PAGE, and the polypeptides were detected by immunoblotting for $\alpha_{1 \mathrm{~B}}(718-963)$, syntaxin 1 , and SNAP-25. Phosphorylation of $\alpha_{1 \mathrm{~B}}(718-963)$ with CaM KII inhibited its binding to the immobilized complex containing syn- 
taxin 1 and SNAP-25 (Fig. 8A). No binding to a control mouse IgG immunoprecipitate was observed. PKC phosphorylation similarly reduced binding of $\alpha_{1 \mathrm{~B}}(718-963)$ to the immunoprecipitated complex (Fig. $8 B$ ). The reduction in binding by the phosphorylated $\alpha_{1 \mathrm{~B}}$ synprint sites was observed in three experiments and validates the studies using recombinant GST-syntaxin 1A and SNAP-25. Furthermore, the results suggest that phosphorylation of the $\alpha_{1 \mathrm{~B}}$ synprint site can inhibit binding to a heterodimeric complex containing native syntaxin and SNAP-25.

\section{DISCUSSION}

\section{Function and phosphorylation of the synprint site in vitro}

Our results show that phosphorylation of synprint peptides within $\mathrm{L}_{\text {II-III }}$ of the N-type calcium channel $\alpha_{1 \mathrm{~B}}$ subunit inhibits the binding of syntaxin 1A and SNAP-25. The effect is mediated by PKC and CaM KII and is dependent on phosphorylation of sites within both the $\mathrm{N}$ - and $\mathrm{C}$-terminal halves of the synprint site. Inhibition of syntaxin $1 \mathrm{~A}$ and SNAP-25 binding to the synprint site by phosphorylation prevents the calcium-dependent interaction of these proteins. Furthermore, association of synprint site polypeptides with SNARE complexes containing native syntaxin and SNAP-25 is inhibited by PKC and CaM KII phosphorylation. The significance of these observations for the regulation of synaptic transmission depends on the ability of the recombinant epitope-tagged fusion proteins to mimic the biochemical characteristics of discrete regions of cognate native proteins in vivo. There are several reasons to expect that this assumption holds for the synprint polypeptides. The region of the synprint site is large and hydrophilic, and in the native calcium channel it is tethered at both ends by membrane-spanning segments, all indicative of a protein folding pathway independent of other domains within the calcium channel. Furthermore, the $\alpha_{1 \mathrm{~B}}$ synprint peptide competitively inhibits the co-immunoprecipitation of native N-type calcium channels with syntaxin, and when introduced into sympathetic neurons in co-culture, specifically inhibits the fast, synchronous component of neurotransmitter release (Mochida et al., 1996). Finally, as shown here, the two-dimensional phosphopeptide maps of synprint peptides are also observed in those of native N-type calcium channel $\alpha_{1 \mathrm{~B}}$ subunits. These results indicate that the synprint peptides fold into functional conformation after bacterial expression.

\section{Phosphorylation of the $\mathbf{N}$-type calcium channel in vitro}

The rat brain $\mathrm{N}$-type calcium channel $\alpha_{1 \mathrm{~B}}$ subunit is a substrate for in vitro phosphorylation by $\mathrm{PKA}, \mathrm{PKG}, \mathrm{PKC}$, and CaM KII (Ahlijanian et al., 1991; Hell et al., 1994). PKA, PKG, and PKC phosphorylate both observed size forms of the $\alpha_{1 \mathrm{~B}}$ subunit, whereas CaM KII primarily phosphorylates the longer form, which is specifically recognized by a C-terminal-directed antibody, suggesting that phosphorylation sites for CaM KII reside primarily in the C-terminal region (Hell et al., 1994). Twodimensional tryptic phosphopeptide mapping of the native rat brain $\alpha_{1 \mathrm{~B}}$ subunit compared with the $\alpha_{1 \mathrm{~B}}$ synprint peptide (Fig. 3) indicates that PKC and CaM KII phosphorylation sites within the synprint peptide are also phosphorylated in the native $\mathrm{N}$-type calcium channel, consistent with the hypothesis that these sites are phosphorylated in the intact channel in situ. As expected, the greater complexity of phosphopeptide maps from the native calcium channel compared with the synprint polypeptides reflects the availability of kinase substrate sites in other intracellular domains of the $\alpha_{1 \mathrm{~B}}$ subunit. In contrast, sites observed in the synprint polypeptide but not in the native channel may be caused by altered local conformations of the fusion polypeptide or limitations to kinase access to sites in the native channel attributable to endogenous SNARE proteins bound at the synprint site. Additionally, phosphorylation sites in the native channel may be underrepresented or absent in vitro because phosphorylation of those sites in vivo may occlude incorporation of ${ }^{32} \mathrm{P}$ by exogenous kinases. Nevertheless, our results show that a subset of phosphorylation sites in the synprint peptides are also phosphorylated in the intact $\mathrm{N}$-type calcium channel.

\section{Phosphorylation of the $\mathrm{N}$-type calcium channel in vivo}

Stimulation of hippocampal neurons by activators of PKA or by depolarization with the potassium channel blocker tetraethylammonium increases in vivo phosphorylation of the $\alpha_{1 \mathrm{~B}}$ subunit of N-type calcium channels by PKA (Hell et al., 1995); however, PKA, PKG, and CaM KII activation do not appear to alter $\mathrm{N}$-type calcium channel current in rat sympathetic neurons (Bernheim et al., 1991; Zhu and Ikeda, 1994). In contrast, the effect of PKC on the modulation of N-type channels is clearly demonstrated (Diversé-Pierluissi and Dunlap, 1993; Swartz, 1993; Swartz et al., 1993; Yang and Tsien, 1993, Diverse-Pierluissi et al., 1995). In many neurons, PKC enhances N-type calcium current via the reversal of tonic G-protein-mediated inhibition (Swartz, 1993; Swartz et al., 1993), and in other studies PKC has been found to increase $\mathrm{N}$-type calcium currents in the absence of G-protein inhibition (Yang and Tsien, 1993) or elicit a steadystate inhibition (Diversé-Pierluissi et al., 1995). Studies of these effects with $\mathrm{N}$-type calcium channels expressed in Xenopus oocytes identified several consensus PKC sites in $\mathrm{L}_{\mathrm{I}-\mathrm{II}}$ of $\alpha_{1 \mathrm{~B}}$ that are responsible for modulation (Stea et al., 1995; Zamponi et al., 1997). Given these findings, it is unlikely that phosphorylation of the synprint site by PKC or CaM KII directly alters channel gating.

\section{Regulation of $\mathrm{N}$-type calcium channels by interaction with SNARE proteins}

Co-expression of syntaxin with $\mathrm{N}$-type calcium channels in $\mathrm{Xe}$ nopus oocytes causes a negative shift in the voltage dependence of inactivation that reduces calcium channel activity (Bezprozvanny et al., 1995; Wiser et al., 1996). This direct inhibitory interaction has not yet been observed in neurons. Injection of synprint peptides into sympathetic ganglion neurons inhibited synaptic transmission but did not affect N-type calcium currents measured in the cell body (Mochida et al., 1996); however, it is not known whether syntaxin interacts with N-type calcium channels in the cell body. Cleavage of syntaxin in isolated nerve terminals prevented G-protein inhibition but did not affect the voltage dependence of inactivation (Stanley and Mirotznik, 1997). Thus, it remains uncertain whether an interaction with SNARE proteins directly inhibits calcium channel activity in neurons. If the direct inhibitory effects observed in Xenopus oocytes also occur in neurons, our results suggest that these inhibitory effects would be reversed by phosphorylation of the synprint site by $\mathrm{PKC}$ or $\mathrm{CaM}$ KII, resulting in increased calcium channel activity. In addition, phosphorylation of the synprint site might also increase calcium channel activity indirectly by relieving G-protein inhibition, as observed in isolated nerve terminals.

\section{Regulation of SNARE complex interactions by phosphorylation of the SNARE proteins}

The binding properties of several SNARE and SNAREassociated proteins are altered by phosphorylation, including the 
inhibition of Munc-18 interactions with syntaxin by PKC (Fujita et al., 1996), inhibition of $\alpha$ SNAP binding to the SNARE complex by PKA (Hirling and Scheller, 1996), and inhibition of SNAP-25 binding to syntaxin by PKC (Shimazaki et al., 1996). Although syntaxin is a substrate for CaM KII and SNAP-25 for both CaM KII and PKC (Hirling and Scheller, 1996; Shimazaki et al., 1996), we did not observe any effect of phosphorylation by these kinases on interactions with the synprint site polypeptides. Thus, the interactions of SNARE proteins with N-type calcium channels are not likely to be regulated by phosphorylation of the SNARE proteins by PKC and CaM KII, even though their interactions with other proteins are affected.

\section{Possible physiological significance of synprint site phosphorylation}

Modulation of the interaction between N-type calcium channels and SNARE proteins by phosphorylation is a candidate presynaptic mechanism for the regulation of neurotransmission. Both PKC and CaM KII enhance synaptic transmission (Shapira et al., 1987; Capogna et al., 1995; Nicoll and Malenka, 1995; Gillis et al., 1996). The simplest prediction from our data and previous work demonstrating inhibitory effects of injected synprint site peptides on synaptic transmission (Mochida et al., 1996) is that PKC or CaM KII phosphorylation of the synprint site in N-type channels should result in the inhibition of neurotransmission. On the other hand, it is likely that the interactions between $\mathrm{N}$-type calcium channels and SNARE proteins are reversed at high calcium concentration in the final steps of the release process (Sheng et al., 1996); therefore, PKC or CaM KII phosphorylation of the synprint site could increase the rate of vesicle fusion by decreasing an energy barrier or releasing an inhibitory influence at a late step of exocytosis. A specific example of such a mechanism would be release of syntaxin from the calcium channel to allow its interaction with synaptotagmin, the calcium sensor in regulated exocytosis. Phosphorylation of the synprint site might also reverse the inhibitory effect of syntaxin or G-proteins or both on calcium channel activity, which would enhance synaptic transmission indirectly.

Some forms of synaptic plasticity suggest presynaptic inhibitory effects of CaM KII or PKC. Heterozygous CaM KII knockout mice exhibit significantly increased post-tetanic potentiation compared with wild-type mice, suggesting that a normal role for the basal activity of CaM KII is the presynaptic suppression of transmitter release (Chapman et al., 1995). This effect is consistent with the inhibition of synprint binding by CaM KII. Similarly, mice expressing a transgene encoding a constitutively activated form of CaM KII show enhanced long-term depression (LTD) within a discrete range of stimulus frequency (Mayford et al., 1995), and effects of activation of PKC on the priming of LTD and suppression of long-term potentiation are also reported (Stanton, 1995). Phosphorylation of the synprint site may contribute to these effects also. For example, PKC or CaM KII phosphorylation of the synprint site may inhibit synaptic transmission at intermediate calcium levels, and depolarization- and calciumdependent activation of a phosphatase at increased calcium concentrations may strengthen interactions with the SNARE proteins and allow increased transmitter release.

Analysis of the physiological roles of phosphorylation of the synprint site of N-type calcium channels will require identification of the specific phosphorylation sites involved in regulation of interactions with SNARE proteins and correlation of their phos- phorylation with changes in synaptic function in intact neuronal preparations.

\section{REFERENCES}

Ahlijanian MK, Striessnig J, Catterall WA (1991) Phosphorylation of an $\alpha 1$-like subunit of an $\omega$-conotoxin-sensitive brain calcium channel by cAMP-dependent protein kinase and protein kinase C. J Biol Chem 266:20192-20197.

Bennett MK, Calakos N, Scheller RH (1992) Syntaxin: a synaptic protein implicated in docking of synaptic vesicles at presynaptic active zones. Science 257:255-260.

Bernheim L, Beech DJ, Hille B (1991) A diffusible second messenger mediates one of the pathways coupling receptors to calcium channels in rat sympathetic neurons. Neuron 6:859-867.

Bezprozvanny I, Scheller RH, Tsien RW (1995) Functional impact of syntaxin on gating of N-type and Q-type calcium channels. Nature 378:623-626.

Brickey DA, Colbran RJ, Fong YL, Soderling TR (1990) Expression and characterization of the $\alpha$ subunit of $\mathrm{Ca}^{2+} /$ calmodulin-dependent protein kinase II using the baculovirus expression system. Biochem Biophys Res Commun 173:578-584.

Capogna M, Gahwiler BH, Thompson SM (1995) Presynaptic enhancement of inhibitory synaptic transmission by protein kinases $\mathrm{A}$ and $\mathrm{C}$ in the rat hippocampus in vitro. J Neurosci 15:1249-1260.

Catterall WA (1994) Modulation of ion channels by protein phosphorylation. In: Cellular and molecular mechanisms underlying higher neural functions (Selverston AI, Ascher P, eds), pp 275-289. New York: Wiley.

Chapman ER, An S, Barton N, Jahn R (1994) SNAP-25, a t-SNARE which binds to both syntaxin and synaptobrevin via domains that may form coiled coils. J Biol Chem 269:27427-27432.

Chapman PF, Frenguelli BG, Smith A, Chen C-M, Silva AJ (1995) The $\alpha-\mathrm{Ca}^{2+} /$ calmodulin kinase II: a bidirectional modulator of presynaptic plasticity. Neuron 14:591-597.

Diversé-Pierluissi M, Dunlap K (1993) Distinct, convergent second messenger pathways modulate neuronal calcium currents. Neuron 10:753-760.

Diversé-Pierluissi M, Goldsmith PK, Dunlap K (1995) Transmittermediated inhibition of N-type calcium channels in sensory neurons involves multiple GTP binding proteins and subunits. Neuron 14:191200.

Doucet J-P, Murphy BJ, Tuana BS (1990) Modification of a discontinuous and highly porous sodium dodecyl sulfate-polyacrylamide gel system for minigel electrophoresis. Anal Biochem 190:209-211.

Dubel SJ, Starr TV, Hell J, Ahlijanian MK, Enyeart JJ, Catterall WA, Snutch TP (1992) Molecular cloning of the $\alpha 1$ subunit of an $\omega$-conotoxin-sensitive calcium channel. Proc Natl Acad Sci USA 89:5058-5062.

Dunlap K, Luebke JI, Turner TJ (1995) Exocytotic $\mathrm{Ca}^{2+}$ channels in mammalian central neurons. Trends Neurosci 18:89-98.

Fujita Y, Sasaki T, Fukui K, Kotani H, Kimura T, Hata Y, Sudhof TC, Scheller RH, Takai Y (1996) Phosphorylation of Munc-18/n-Sec1/rbSec1 by protein kinase $\mathrm{C}$ : its implication in regulating the interaction of Munc-18/n-Sec1/rbSec1 with syntaxin. J Biol Chem 271:7265-7268.

Gillis KD, Mossner R, Neher E (1996) Protein kinase C enhances exocytosis from chromaffin cells by increasing the size of the readily releasable pool of secretory granules. Neuron 16:1209-1220.

Hell JW, Appleyard SM, Yokoyama CT, Warner C, Catterall WA (1994) Differential phosphorylation of two size forms of the N-type calcium channel $\alpha 1$ subunit which have different $\mathrm{COOH}$ termini. J Biol Chem 269:7390-7396.

Hell JW, Yokoyama CT, Breeze LJ, Chavkin C, Catterall WA (1995) Phosphorylation of presynaptic and postsynaptic calcium channels by cAMP-dependent protein kinase in hippocampal neurons. EMBO J 14:3036-3044.

Hirling H, Scheller RH (1996) Phosphorylation of synaptic vesicle proteins: modulation of the $\alpha$ SNAP interaction with the core complex. Proc Natl Acad Sci USA 93:11945-11949.

Hirning LD, Fox AP, McCleskey EW, Olivera BM, Thayer SA, Miller RJ, Tsien RW (1988) Dominant role of N-type $\mathrm{Ca}^{2+}$ channels in evoked release of norepinephrine from sympathetic neurons. Science 239:57-61.

Kaczmarek LK, Jennings KR, Strumwasser F, Nairn AC, Walter U, Wilson FD, Greengard P (1980) Microinjection of catalytic subunit of cAMP-dependent protein kinase enhances calcium action potentials of bag cell neurons in cell culture. Proc Natl Acad Sci USA 77:7487-7491. 
Leveque C, Hoshino T, David P, Shoji-Kasai Y, Leys K, Omori A, Lang B, El Far O, Sato K, Martin-Moutot N, Newsom-Davis J, Takahashi M, Seagar MJ (1992) The synaptic vesicle protein synaptotagmin associates with calcium channels and is a putative Lambert-Eaton myasthenic syndrome antigen. Proc Natl Acad Sci USA 89:3625-3629.

Leveque C, El Far O, Martin Moutot N, Sato K, Kato R, Takahashi M, Seagar MJ (1994) Purification of the N-type calcium channel associated with syntaxin and synaptotagmin. A complex implicated in synaptic vesicle exocytosis. J Biol Chem 269:6306-6312.

Levitan IB (1994) Modulation of ion channels by protein phosphorylation and dephosphorylation. Annu Rev Physiol 56:193-212.

Luebke JI, Dunlap K, Turner TJ (1993) Multiple calcium channel types control glutamatergic synaptic transmission in the hippocampus. Neuron 11:895-902.

Martin-Moutot N, Charvin N, Leveque C, Sato K, Nishiki T, Kozaki S, Takahashi M, Seagar M (1996) Interaction of SNARE complexes with $\mathrm{P} / \mathrm{Q}$-type calcium channels in rat cerebellar synaptosomes. J Biol Chem 271:6567-6570.

Mayford M, Wang J, Kandel ER, O'Dell TJ (1995) CaMKII regulates the frequency-response function of hippocampal synapses for the production of both LTD and LTP. Cell 81:891-904.

Mochida S, Sheng ZH, Baker C, Kobayashi H, Catterall WA (1996) Inhibition of neurotransmission by peptides containing the synaptic protein interaction site of $\mathrm{N}$-type $\mathrm{Ca}^{2+}$ channels. Neuron 17:781-788.

Mori Y, Friedrich T, Kim M, Mikami A, Nakai J, Ruth P, Bosse E, Hofmann F, Flockerzi V, Furuichi T, Mikoshiba K, Imoto K, Tanabe T, Numa S (1991) Primary structure and functional expression from complementary DNA of a brain calcium channel. Nature 350:398-402.

Murphy BJ, Catterall WA (1992) Phosphorylation of purified rat brain $\mathrm{Na}^{+}$channel reconstituted into phospholipid vesicles by protein kinase C. J Biol Chem 267:16129-16134.

Nicoll RA, Malenka RC (1995) Contrasting properties of two forms of long-term potentiation in the hippocampus. Nature 377:115-118.

Rettig J, Sheng ZH, Kim DK, Hodson CD, Snutch TP, Catterall WA (1996) Isoform-specific interaction of the $\alpha_{1 \mathrm{~A}}$ subunits of brain $\mathrm{Ca}^{2+}$ channels with the presynaptic proteins syntaxin and SNAP-25. Proc Natl Acad Sci USA 93:7363-7368.

Reuter H (1995) Measurements of exocytosis from single presynaptic nerve terminals reveal heterogeneous inhibition by $\mathrm{Ca}^{2+}$ channel blockers. Neuron 14:773-779.

Shapira R, Silberberg SD, Ginsburg S, Rahamimoff R (1987) Activation of protein kinase $\mathrm{C}$ augments evoked transmitter release. Nature 325:58-60.

Sheng ZH, Rettig J, Takahashi M, Catterall WA (1994) Identification of a syntaxin-binding site on N-type calcium channels. Neuron 13:1303-1313.

Sheng ZH, Rettig J, Cook T, Catterall WA (1996) Calcium-dependent interaction of $\mathrm{N}$-type calcium channels with the synaptic core complex. Nature 379:451-454.

Shimazaki Y, Nishiki T, Omori A, Sekiguchi M, Kamata Y, Kozaki S, Takahashi M (1996) Phosphorylation of $25 \mathrm{kDa}$ synaptosomeassociated protein. J Biol Chem 271:14548-14553.

Sollner T, Whiteheart SW, Brunner M, Erdjument-Bromage H, Geromanos S, Tempst P, Rothman JE (1993a) SNAP receptors implicated in vesicle targeting and fusion. Nature 362:318-323.

Sollner T, Bennett MK, Whiteheart SW, Scheller RH, Rothman JE (1993b) A protein assembly-disassembly pathway in vitro that may correspond to sequential steps of synaptic vesicle docking, activation, and fusion. Cell 75:409-418.

Stanley EF, Mirotznik RR (1997) Cleavage of syntaxin prevents G-protein regulation of presynaptic calcium channels. Nature 385:340-343.

Stanton PK (1995) Transient protein kinase C activation primes longterm depression and suppresses long-term potentiation of synaptic transmission in hippocampus. Proc Natl Acad Sci USA 92:1724-1728.

Starr TVB, Prystay W, Snutch TP (1991) Primary structure of a calcium channel that is highly expressed in the rat cerebellum. Proc Natl Acad Sci USA 88:5621-5625.

Stea A, Soong TW, Snutch TP (1995) Determinants of PKC-dependent modulation of a family of neuronal calcium channels. Neuron 15:929-940.

Sudhof TC (1995) The synaptic vesicle cycle: a cascade of proteinprotein interactions. Nature 375:645-653.

Swartz KJ (1993) Modulation of $\mathrm{Ca}^{2+}$ channels by protein kinase $\mathrm{C}$ in rat central and peripheral neurons: disruption of $\mathrm{G}$ protein-mediated inhibition. Neuron 11:305-320.

Swartz KJ, Merritt A, Bean BP, Lovinger DM (1993) Protein kinase C modulates glutamate receptor inhibition of $\mathrm{Ca}^{2+}$ channels and synaptic transmission. Nature 361:165-168.

Westenbroek RE, Hell JW, Warner C, Dubel SJ, Snutch TP, Catterall WA (1992) Biochemical properties and subcellular distribution of an N-type calcium channel $\alpha 1$ subunit. Neuron 9:1099-1115.

Westenbroek RE, Sakurai T, Elliott EM, Hell JW, Starr TVB, Snutch TP, Catterall WA (1995) Immunochemical identification and subcellular distribution of the $\alpha_{1 \mathrm{~A}}$ subunits of brain calcium channels. J Neurosci 15:6403-6418.

Wheeler DB, Randall A, Tsien RW (1994) Roles of N-type and Q-type $\mathrm{Ca}^{2+}$ channels in supporting hippocampal synaptic transmission. Science 264:107-111.

Wiser O, Bennett MK, Atlas D (1996) Functional interaction of syntaxin and SNAP-25 with voltage-sensitive L- and N-type $\mathrm{Ca}^{2+}$ channels. EMBO J 15:4100-4110.

Woodgett JR, Hunter T (1987) Isolation and characterization of two distinct forms of protein kinase C. J Biol Chem 262:4836-4843.

Yang J, Tsien RW (1993) Enhancement of N- and L-type calcium channel currents by protein kinase $\mathrm{C}$ in frog sympathetic neurons. Neuron 10:127-136.

Yokoyama CT, Westenbroek RE, Hell JW, Soong TW, Snutch TP, Catterall WA (1995) Biochemical properties and subcellular distribution of the neuronal class E calcium channel $\alpha 1$ subunit. J Neurosci 15:6419-6432.

Yoshida A, Oho C, Omori A, Kawahara R, Ito T, Takahashi M (1992) HPC-1 is associated with synaptotagmin and $\omega$-conotoxin receptor. J Biol Chem 267:24925-24928.

Zamponi GW, Bourinet E, Nelson D, Nargeot J, Snutch TP (1997) Crosstalk between $\mathrm{G}$ proteins and protein kinase $\mathrm{C}$ mediated by the calcium channel $\alpha 1$ subunit. Nature 385:442-446.

Zhu Y, Ikeda SR (1994) VIP inhibits N-type $\mathrm{Ca}^{2+}$ channels of sympathetic neurons via a pertussis toxin-insensitive but cholera toxinsensitive pathway. Neuron 13:657-669.

Zucker RS (1996) Exocytosis: a molecular and physiological perspective. Neuron 17:1049-1055. 